\title{
Delta cell death in the islet of Langerhans and the progression from normal glucose tolerance to type 2 diabetes in non-human primates (baboon, Papio hamadryas)
}

\author{
Rodolfo Guardado Mendoza ${ }^{1,2,3}$ - Carla Perego ${ }^{4}$ Giovanna Finzi ${ }^{5,6} \cdot$ Stefano La Rosa ${ }^{5,6}$ • \\ Carlo Capella ${ }^{5,6}$ - Lilia M. Jimenez-Ceja ${ }^{1,3} \cdot$ Licio A. Velloso $^{7}$ - Mario J. A. Saad ${ }^{7}$ • \\ Fausto Sessa $^{5,6}$ • Federico Bertuzzi $^{8}$ • Stefania Moretti ${ }^{4}$ - Edward J. Dick Jr. ${ }^{9}$. \\ Alberto M. Davalli ${ }^{10}$. Franco Folli ${ }^{1,7,11}$
}

Received: 5 February 2015 / Accepted: 21 April 2015 /Published online: 7 June 2015

(C) Springer-Verlag Berlin Heidelberg 2015

\begin{abstract}
Aims/hypothesis The cellular composition of the islet of Langerhans is essential to ensure its physiological function. Morphophysiological islet abnormalities are present in type 2 diabetes but the relationship between fasting plasma glucose (FPG) and islet cell composition, particularly the role of delta cells, is unknown. We explored these questions in pancreases from baboons (Papio hamadryas) with FPG ranging from normal to type 2 diabetic values.

Methods We measured the volumes of alpha, beta and delta cells and amyloid in pancreatic islets of 40 baboons (Group 1 [G1]: $\mathrm{FPG}<4.44 \mathrm{mmol} / 1[n=10] ; \mathrm{G} 2: \mathrm{FPG}=4.44-5.26 \mathrm{mmol} / \mathrm{l}$ $[n=9] ;$ G3: FPG $=5.27-6.94 \mathrm{mmol} / 1[n=9] ;$ G4: FPG $>$ $6.94 \mathrm{mmol} / 1[n=12])$ and correlated islet composition with metabolic and hormonal variables. We also performed confo-
\end{abstract}

Electronic supplementary material The online version of this article (doi:10.1007/s00125-015-3625-5) contains peer-reviewed but unedited supplementary material, which is available to authorised users.

Franco Folli

folli@uthscsa.edu

1 Department of Medicine, Diabetes Division, University of Texas Health Science Center at San Antonio, 7703 Floyd Curl Drive, San Antonio, TX 78229-3900, USA

2 Research Department, Hospital Regional de Alta Especialidad del Bajío, León, Guanajuato, Mexico

3 Department of Medicine and Nutrition, Division of Health Sciences, University of Guanajuato, León, Guanajuato, Mexico

4 Dipartimento di Scienze Farmacologiche e Biomolecolari, Universitá degli Studi di Milano, Milan, Italy

5 Department of Pathology, Ospedale di Circolo, University of Insubria, Varese, Italy cal microscopy including TUNEL, caspase-3, and anti-caspase cleavage product of cytokeratin 18 (M30) immunostaining, electron microscopy, and immuno-electron microscopy with anti-somatostatin antibodies in baboon pancreases.

Results Amyloidosis preceded the decrease in beta cell volume. Alpha cell volume increased $\sim 50 \%$ in G3 and G4 $(p<0.05)$, while delta cell volume decreased in these groups by $31 \%$ and $39 \%$, respectively $(p<0.05)$. In $\mathrm{G} 4$, glucagon levels were higher, while insulin and HOMA index of beta cell function were lower than in the other groups. Immunostaining of G4 pancreatic sections with TUNEL, caspase-3 and M30 showed apoptosis of beta and delta cells, which was also confirmed by immuno-electron microscopy with anti-somatostatin antibodies. Conclusions/interpretation In diabetic baboons, changes in islet composition correlate with amyloid deposition, with in-

Department of Surgical and Morphological Sciences, University of Insubria, Varese, Italy

7 Department of Medicine, Obesity and Comorbidities Research Center (OCRC), University of Campinas, Campinas, São Paulo State, Brazil

8 Ospedale Niguarda, Milan, Italy

9 Southwest National Primate Research Center, Texas Biomedical Research Institute, San Antonio, TX, USA

10 Department of Medicine and Endocrinology, Ospedale San Raffaele, Milan, Italy

11 Department of Genetics, Texas Biomedical Research Institute, San Antonio, TX, USA 
creased alpha cell and decreased beta and delta cell volume and number due to apoptosis. These data argue for an important role of delta cells in type 2 diabetes.

Keywords Alpha cell $\cdot$ Amyloid $\cdot$ Apoptosis $\cdot$ Baboon $\cdot$ Beta cell · Delta cell · Islet of Langerhans · Islet remodelling . Non-human primates $\cdot$ Papio hamadryas Type 2 diabetes mellitus
Abbreviations
CAST Computer assisted stereology toolbox
CC-3 Anti-cleaved caspase 3 (Asp175) immunostaining
FPG Fasting plasma glucose
FPI Fasting plasma insulin
IFG Impaired fasting glucose
M30 Anti-caspase cleavage product of cytokeratin 18
NGT Normal glucose tolerance

\section{Introduction}

Plasma glucose levels are tightly regulated by the islets of Langerhans in concert with insulin target tissues. Islets have a complex multi-cellular structure, containing insulin-secreting beta cells, glucagon-secreting alpha cells, somatostatin-secreting delta cells, pancreatic-polypeptide-secreting PP cells and grehlin-secreting epsilon cells. Physiological interactions between these different cell types are essential to ensure appropriate islet function, and changes in islet architecture have functional implications [1-7]. Compared with rodent islets, human and baboon islets contain proportionally fewer beta cells and more alpha cells [8-11]. In rodents, endocrine non-beta cells are confined to the islet periphery (mantle) while beta cells are concentrated in the centre (core) [12]. In sharp contrast, the vast majority of human and baboon islets do not have a core-mantle structure, as the beta cells are intermingled with alpha and delta cells throughout the islet and all the endocrine cells have equivalent access to blood vessels [8-10]. Therefore, human and baboon alpha and delta cells may exert a stronger paracrine control of the adjacent beta cells than those of rodents.

Islet composition undergoes profound changes in humans and non-human primates with type 2 diabetes, with a 50-70\% reduction in beta cell mass and a variable absolute or relative increase in alpha cell numbers [13,14], which account for the defective insulin secretion and the hyperglucagonaemia that are distinctive features of the disease [15-17]. However, studies of islet cell composition in humans have the following limitations: (1) they are necessarily performed on autoptic pancreases obtained $48-72 \mathrm{~h}$ post mortem when autolysis causes cell damage; (2) the vast majority of studies have compared non-diabetic vs diabetic subjects and have not examined islet composition in different stages of glucose intolerance; (3) the different glucose-lowering regimens represent an additional confounding factor $[18,19]$; and (4) most of the studies do not show correlations between morphometric and biochemical/functional variable parameters.

Delta cell fate in the diabetic pancreas is presently unknown, even though these cells may be more important than commonly thought [2-4]. A heterocellular region in which alpha, delta and beta cells are in close proximity has been described in the islets of all species and is believed to function as a pacemaker for the entire islet under the control of the delta cells $[2,3,20]$. However, information about delta cell number and function in diabetes is limited and whether these cells are also involved in the pathogenesis of diabetes remains unclear. Nevertheless, several lines of evidence support a role of delta cells in the pathogenesis of diabetes. Somatostatin receptors are present on both alpha and beta cells [21], and somatostatin secreted by delta cells paracrinally controls alpha and beta cell function [22, 23]. Major physiological insulin secretagogues such as glucose, arginine and glucagon-like peptide-1 (GLP-1) also regulate somatostatin release [22-28]. Finally, transgenic mice depleted of delta cells ( $\mathrm{Sst} \mathrm{t}^{--}$mice) show enhanced insulin and glucagon release in response to nutrient stimuli [22], suggesting that delta cells exert a tonic inhibitory influence on insulin and glucagon secretion and are implicated in nutrientinduced suppression of glucagon secretion.

Baboons are an interesting model of spontaneous obesity, insulin resistance and type 2 diabetes in humans [29-33]. In the present study, we analysed the islet cell composition of 40 baboons obtained from a large cohort. The fasting plasma glucose (FPG) concentrations of the baboons were measured in the last year of their lives and the volumes of the islets of Langerhans, beta, alpha and delta cells and amyloid deposits were measured in pancreases. The relationships between changes in islet cell composition and FPG, clinical, biochemical and metabolic variables were investigated.

\section{Methods}

Study population The study was conducted in accordance with the Principles of Laboratory Care in baboons that died from natural causes, with similar age and weight and different levels of FPG, (Group 1 [G1]: FPG $<4.44 \mathrm{mmol} / 1$ [ $n=10]$; G2: $\mathrm{FPG}=4.44-5.26 \mathrm{mmol} / \mathrm{l}[n=9] ; \mathrm{G} 3: \mathrm{FPG}=5.27-6.94 \mathrm{mmol} / \mathrm{l}$ $[n=9]$; G4: FPG $>6.94 \mathrm{mmol} / \mathrm{l}[n=12])$ selected from a large cohort followed during the past 14 years (from 1994 to 2007) at the Texas Biomedical Research Institute. Inclusion criteria were: (1) older than 8 years; and (2) availability of pancreatic tissue and clinical, anthropometric and laboratory measurements. Forty baboons were included in the present work (Table 1). Animals were fed ad libitum with a standard monkey chow (diet 5038, Purina, St Louis, MO, USA) and housed in corrals where they performed unrestrained physical activity. 
Table 1 Clinical, biochemical and morphological characteristics of the different groups according to glucose levels

\begin{tabular}{|c|c|c|c|c|c|}
\hline Variable & $\begin{array}{l}\text { Group } 1 \text { (FPG: } \\
<4.44 \mathrm{mmol} / \mathrm{l})\end{array}$ & $\begin{array}{l}\text { Group } 2 \text { (FPG: } \\
4.44-5.26 \mathrm{mmol} / \mathrm{l})\end{array}$ & $\begin{array}{l}\text { Group } 3 \text { (FPG: } \\
5.27-6.94 \mathrm{mmol} / \mathrm{l})\end{array}$ & $\begin{array}{l}\text { Group } 4 \text { (FPG: } \\
>6.94 \mathrm{mmol} / \mathrm{l})\end{array}$ & $p$ value \\
\hline $\begin{array}{l}\text { Baboons }(n) \\
\quad(\text { total } N=40)\end{array}$ & 10 & 9 & 9 & 12 & \\
\hline Age (years) & $21.9 \pm 1.0$ & $19.8 \pm 0.9$ & $22.0 \pm 1.4$ & $21.2 \pm 0.9$ & 0.469 \\
\hline $\operatorname{Sex}(F / M)$ & $6 / 4$ & $6 / 3$ & $6 / 3$ & $10 / 2$ & 0.252 \\
\hline \multicolumn{6}{|l|}{ Weight (kg) } \\
\hline Females & $17.8 \pm 2.1$ & $15.5 \pm 0.7$ & $19.5 \pm 2.5$ & $19.6 \pm 2.1$ & 0.523 \\
\hline Males & $26.4 \pm 2.0$ & $28.5 \pm 1.2$ & $27.7 \pm 0.7$ & $25.8 \pm 3.0$ & 0.755 \\
\hline FPG $(\mathrm{mmol} / \mathrm{l})$ & $3.98 \pm 0.11$ & $4.72 \pm 0.07$ & $5.78 \pm 0.16$ & $13.10 \pm 1.62^{*}$ & $<0.001$ \\
\hline NEFA (mmol/l) & $0.43 \pm 0.1$ & $0.52 \pm 0.1$ & $0.73 \pm 0.1$ & $1.2 \pm 0.3^{*}$ & 0.001 \\
\hline $\log _{\mathrm{e}}$ insulin $(\mathrm{pmol} / \mathrm{l})$ & $11.2 \pm 0.2$ & $11.5 \pm 0.4$ & $11.8 \pm 0.5$ & $9.8 \pm 0.6^{\ddagger}$ & 0.024 \\
\hline $\log _{\mathrm{e}}$ glucagon (ng/l) & $11.0 \pm 0.1$ & $11.0 \pm 0.1$ & $11.1 \pm 0.1$ & $11.6 \pm 0.2^{*, \dagger}$ & 0.002 \\
\hline Cholesterol (mmol/l) & $2.0 \pm 0.2$ & $2.6 \pm 0.2$ & $2.7 \pm 0.2$ & $3.5 \pm 0.5^{*}$ & 0.003 \\
\hline $\log _{\mathrm{e}}$ HOMA-B & $6.3 \pm 0.3$ & $5.5 \pm 0.4$ & $5.1 \pm 0.5$ & $2.6 \pm 0.4^{*, \dagger}$, & $<0.001$ \\
\hline $\log _{\mathrm{e}}$ HOMA-IR & $7.6 \pm 0.3$ & $8.0 \pm 0.3$ & $8.5 \pm 0.4$ & $8.3 \pm 0.3$ & 0.064 \\
\hline Islets volume $\% /$ pancreas & $3.2 \pm 0.3$ & $3.3 \pm 0.4$ & $3.9 \pm 1.1$ & $4.4 \pm 0.6^{*} \dagger$ & 0.002 \\
\hline Amyloid volume $\% /$ islets & $12.9 \pm 4.6$ & $19.1 \pm 6.3^{*}$ & $33.6 \pm 7.5^{*, \dagger}$ & $70.2 \pm 5.2^{*, \dagger, *}$ & 0.001 \\
\hline Islet size $\left(\mu \mathrm{m}^{2}\right)$ & $9,287 \pm 590$ & $9,294 \pm 960$ & $11,709 \pm 2,511$ & $11,135 \pm 923^{*}, \dagger, \pm$ & 0.002 \\
\hline Beta cell volume/pancreas vol (\%) & $2.1 \pm 0.2$ & $1.9 \pm 0.2$ & $1.9 \pm 0.4$ & $1.0 \pm 0.3^{*}$ & 0.022 \\
\hline Beta cell volume/islet volume (\%) & $60.0 \pm 3.7$ & $60.4 \pm 5.6$ & $50.2 \pm 6.5$ & $23.7 \pm 4.9^{*, \dagger, *}$ & 0.001 \\
\hline Alpha cell volume/pancreas volume (\%) & $0.58 \pm 0.1$ & $0.57 \pm 0.1$ & $0.90 \pm 0.3$ & $0.80 \pm 0.1$ & 0.190 \\
\hline Alpha cell volume/islet volume (\%) & $16.7 \pm 1.0$ & $18.3 \pm 2.8$ & $26.9 \pm 5.0^{*}, \dagger$ & $24.0 \pm 1.9^{*}$ & 0.018 \\
\hline Delta cell volume/pancreas volume (\%) & $0.14 \pm 0.01$ & $0.12 \pm 0.01$ & $0.08 \pm 0.02$ & $0.09 \pm 0.02$ & 0.210 \\
\hline Delta cell volume/islet volume (\%) & $4.7 \pm 0.6$ & $4.4 \pm 0.8$ & $2.8 \pm 0.7$ & $2.8 \pm 0.5^{*}$ & 0.050 \\
\hline
\end{tabular}

${ }^{*} p<0.05$ vs group 1

${ }^{\dagger} p<0.05$ vs group 2

${ }^{\star} p<0.05$ vs group 3

F, female; M, male

Tissue processing Complete necropsies were performed on all the baboons, approximately $6-18 \mathrm{~h}$ post mortem. Pancreatic tissue from the body-tail region was fixed in $10 \%$ neutral-buffered formalin, processed conventionally and embedded in paraffin blocks. Sequential $5 \mu \mathrm{m}$ sections for each baboon were stained with haematoxylin and eosin and Congo red and immunostained with antibodies for insulin, glucagon and somatostatin for evaluation of islets, amyloid deposits, and beta, alpha and delta cell morphometry, respectively. The detailed description of the automated immunohistochemistry, electron microscopy and immuno-electron microscopy is available in the electronic supplementary material (ESM) Methods section.

Morphological measurements The Computer Assisted Stereology Toolbox (CAST) 2.0 system (Olympus, Ballerup, Denmark) was used to perform all the microscopic measurements of beta, alpha and delta cell and amyloid deposit volume using the stereology fundamentals previously described and validated [31, 33-35]. The person who performed the microscopic measurements (RGM) was blinded to the metabolic status of each baboon and the reproducibility of the CAST measurements was estimated twice in five specimens with a coefficient of variation $<5 \%$.

Apoptosis assessment To identify apoptotic cells we analysed pancreas sections derived from a total of eight G1 (normal glucose tolerant [NGT]) and eight G4 (type 2 diabetic) baboons, and three different methods were employed: (1) TUNEL; (2) anti-cleaved caspase 3 (Asp175) immunostaining (CC-3); and (3) anti-caspase cleavage product of cytokeratin 18 (M30). The detailed description of immunofluorescence and confocal microscopy methods is available in ESM Methods.

Apoptosis quantification in beta and delta cells To quantify the percentage of apoptotic cells in each section, the number of M30-positive and TUNEL-positive delta or beta cells was counted in a total of 100 somatostatin-immunoreactive delta cells and 100 insulin-immunoreactive beta cells in three 
different animals from each group, blind, by two different observers (SL and CP). Cells were counted in sequence, in different islets, until the number of 100 beta and 100 delta cells was reached. Statistical evaluation was performed using the unpaired $t$ test.

Analytical measurements Blood glucose was measured by the glucose oxidase method with the SYNCHRON CX System (Beckman Coulter, Brea CA, USA), insulin levels by RIA (Linco Research, St Louis, MO, USA), glucagon by RIA (Euro-Diagnostica AB, Malmö,
Sweden) and NEFA concentrations were determined using the fluorometric method.

Calculations Insulin resistance (HOMA-IR) and beta cell function (HOMA-B) were measured as previously described [36].

Statistical analysis Data are presented as means \pm SEM. ANOVA with Bonferroni correction was used as a post hoc test for comparisons between more than two groups when normal distribution was confirmed and Kruskal-Wallis or
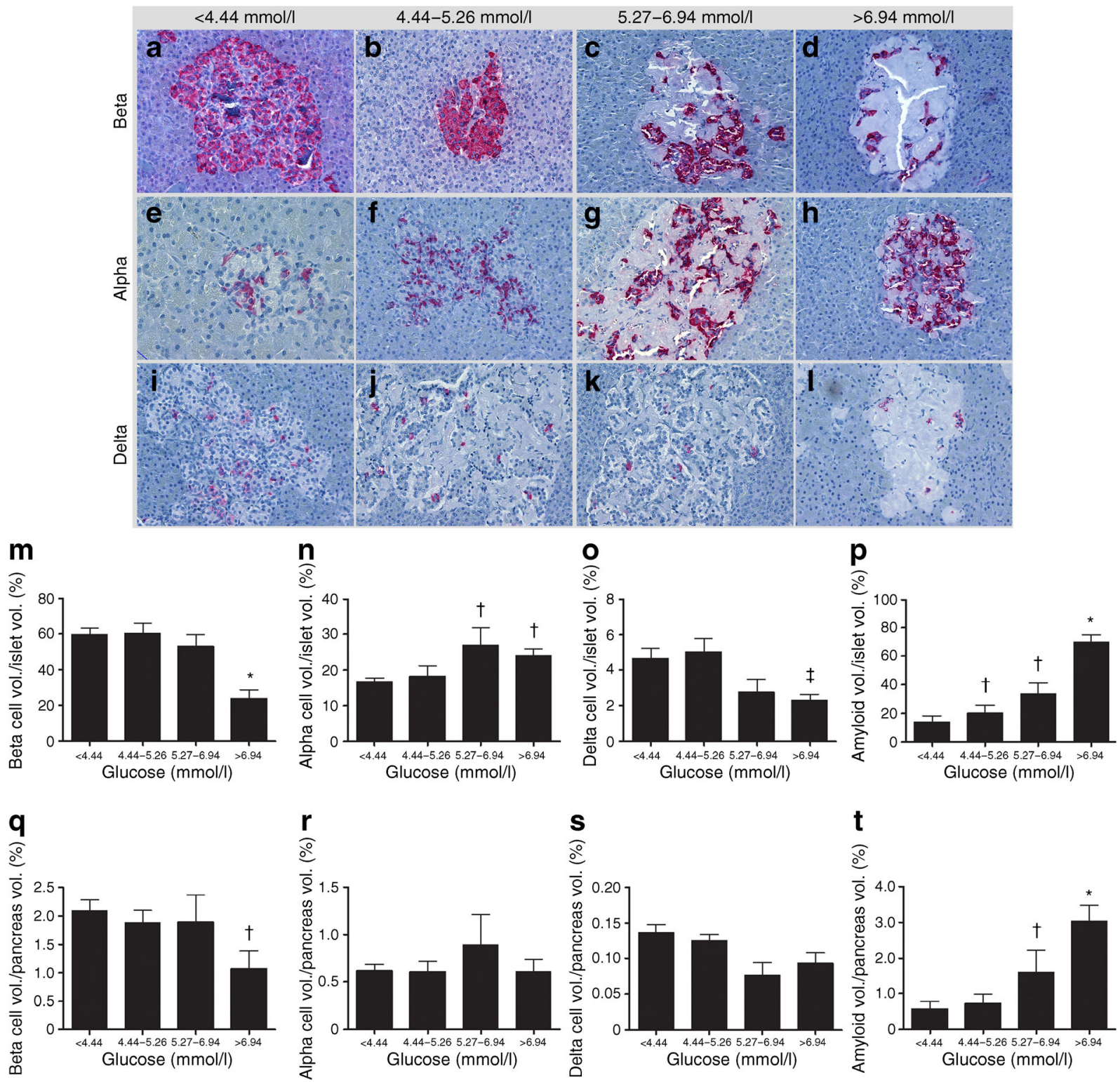

Fig. 1 Morphological islet abnormalities in baboons with progressive increases in glucose levels. (a-d) Progressive decrease in beta cell volume (insulin immunohistochemistry); (e-h) progressive increase in alpha cell volume (glucagon immunohistochemistry); and (i-l) slight decrease in delta cell volume (somatostatin immunohistochemistry). All micrographs show a progressive increase in amyloid severity according to

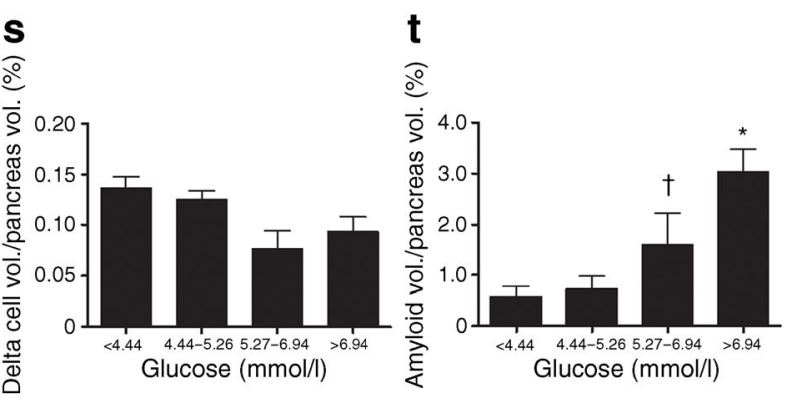

glucose levels (final magnification $\times 40$ ). Quantitative representation of the dysfunctional islet remodelling in the progression to type 2 diabetes: beta, alpha and delta cell and amyloid volumes per islet $(\mathbf{m}-\mathbf{p})$ and per pancreas $(\mathbf{q}-\mathbf{t})$ according to glucose levels in baboons. ${ }^{*} p<0.05$ vs G1, ${ }^{*} p<0.05 \mathrm{G} 3$ vs G1, ${ }^{\dagger} p<0.05$ vs all groups 
$\log$ transformed values were used for those with a skewed distribution, confirming a normal distribution after the log transformation. Bivariable correlations were evaluated with Pearson's correlation coefficient. A $p$ value of $<0.05$ was considered statistically significant.

\section{Results}

Clinical, biochemical and metabolic characteristics Clinical, anthropometric, biochemical and metabolic data, as well as islet volumes, in the four groups are shown in Table 1. FPG increased linearly from G1 to G4; however, only baboons in the G4 group showed the classic diabetic phenotype characterised by: (1) increased plasma glucagon, NEFA and cholesterol levels; (2) decreased FPI levels; and (3) dramatically impaired beta cell function as calculated by HOMA-B. NEFA, cholesterol and HOMA-IR levels tended to increase from G1 to G3, while HOMA-B tended to decline even though these changes were not statistically significant. In addition, islet volume and size did not vary significantly from G1 to G3, while they showed a significant increase in G4.

Islet cell composition and amyloid deposition Islet cell composition and architecture in the four groups is shown in Fig. 1. Figure $1 \mathrm{a}-1$ are representative islets in pancreatic sections stained for insulin (a-d), glucagon (e-h) and somatostatin (i-1). Figure $1 \mathrm{~m}-\mathrm{p}$ are the volumes per islet of beta $(\mathrm{m})$, alpha (n), delta cells (o) and amyloid deposits (p); the same data expressed as the percentage of the entire pancreatic area are shown in Fig. 1q-t. Amyloid volume showed a striking linear increase from G1 to G4 (Fig. 1p, t). The progressive increases in amyloid deposits were not paralleled by significant changes in beta cell volumes that were in fact similar in G1 and G2, slightly decreased in G3 and dramatically reduced only in G4. Alpha cell volumes increased from G1 to G3 where they reached high statistical significance, but did not increase further in G4 (Fig. 1n, r). The volume of somatostatin-secreting delta cells was similar in G1 and G2 but showed a remarkable decrease $(\sim 41 \%)$ in $\mathrm{G} 3$ and $\mathrm{G} 4$ (Fig. 1o, s).

Correlation between severity of amyloid deposition, FPG and islet cell composition The analysis of the correlation between the severity of amyloid deposition, FPG levels and volumes of the three islet cell types is shown in Fig. 2. As expected, amyloid severity showed a linear positive correlation with FPG (Fig. 2a, $R^{2} 0.5275, p<0.001$ ) and an inverse correlation with beta cell volume (Fig. 2b, $R^{2} 0.7679$, $p<0.001)$. By contrast, amyloid deposition and alpha cell volume showed a positive correlation (Fig. 2c, $R^{2} 0.1416$, $p<0.05)$. Finally, the correlation between amyloid deposits and delta cell volume was, similarly to the beta cells, also negative (Fig. 2d, $R^{2} 0.1493, p<0.05$ ).

\section{Correlation between beta cell volume and biochemical and} metabolic variables The relationship between FPG levels and beta cell volume was negative and hyperbolic (Fig. 3a, $R^{2}$ 0.5428, $\left.p<0.001\right)$. Beta cell volume also correlated inversely with NEFA levels (Fig. 3b, $R^{2} 0.2351, p<0.001$ ) and positively with FPI levels and beta cell function calculated
Fig. 2 Correlations between (a) amyloid severity and plasma glucose level $\left(R^{2} 0.5275\right.$, $p<0.001,95 \% \mathrm{CI})$; (b) amyloid severity and beta cell volume/islet volume $\left(R^{2} 0.7679, p<0.001\right.$, $95 \% \mathrm{CI})$; (c) amyloid severity and alpha cell volume/islet volume ( $\left.R^{2} 0.1416, p<0.05,95 \% \mathrm{CI}\right)$; and (d) amyloid severity and delta cell volume/islet volume $\left(R^{2} 0.1493\right.$, $p<0.05,95 \% \mathrm{CI}$ ) in baboons
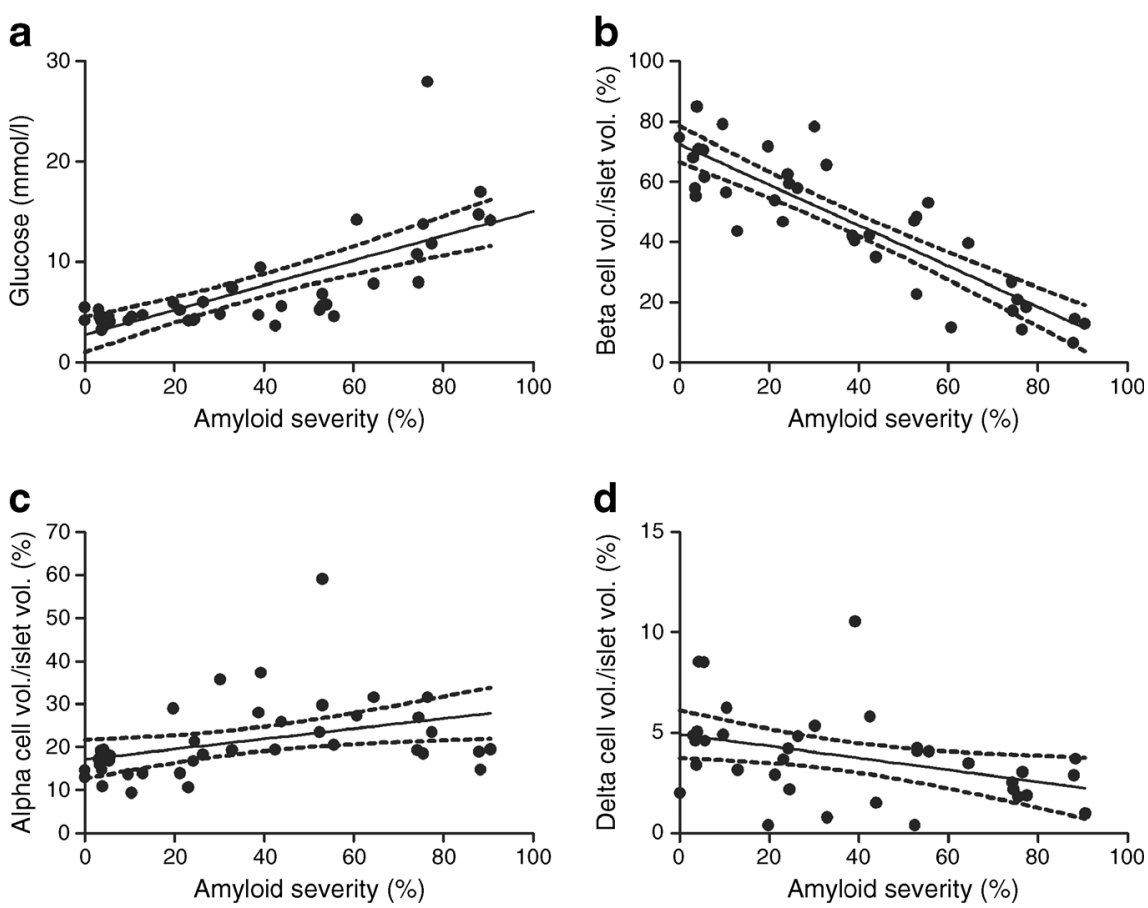
Fig. 3 Correlation between (a) beta cell volume/islet volume and plasma glucose level $\left(R^{2} 0.5428\right.$, $p<0.001$ ); (b) beta cell volume/ islet volume and plasma NEFA level $\left(\log _{\mathrm{e}}\right)\left(R^{2} 0.2351, p<0.001\right.$, $95 \% \mathrm{CI}$ ); (c) beta cell volume/islet volume and plasma insulin level $\left(\log _{\mathrm{e}}\right)\left(R^{2} 0.2946, p<0.001,95 \%\right.$ CI); (d) beta cell volume/islet volume and $\log _{\mathrm{e}}$ HOMA-B $\left(R^{2}\right.$ $0.6092, p<0.001,95 \% \mathrm{CI}$ ); and (e) $\log _{\mathrm{e}}$ HOMA-B and plasma $\log _{\mathrm{e}}$ NEFA $\left(R^{2} 0.2451, p<0.01\right.$, $95 \% \mathrm{CI}$ ) in baboons a

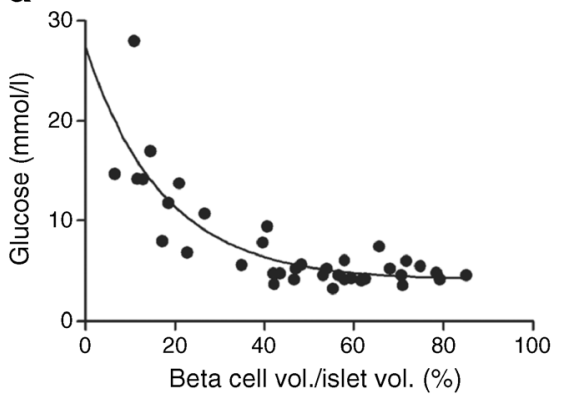

C

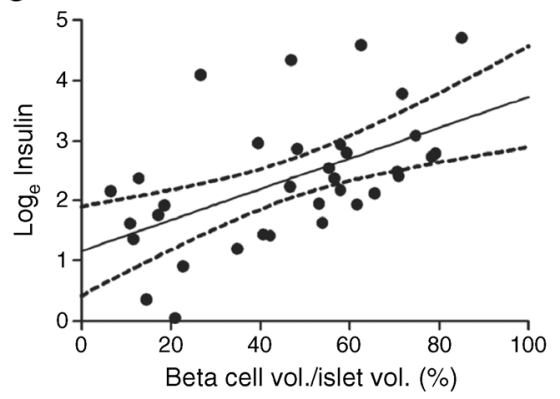

b

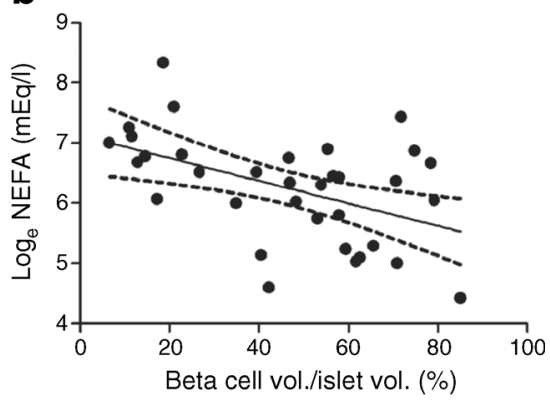

d

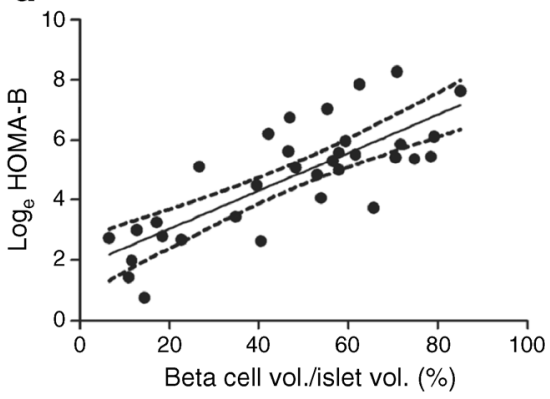

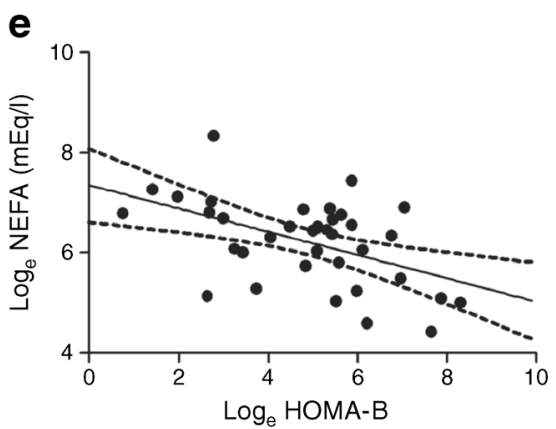

with HOMA-B (Fig. 3c, $R^{2}$ 0.2946, $p<0.001$; Fig. 3d, $R^{2}$ $0.6092, p<0.001)$. HOMA-B was inversely correlated with NEFA levels (Fig. 3e, $R^{2} 0.2451, p<0.01$ ).

\section{Correlation between FPG and NEFA levels and volumes} of alpha and delta cells The correlations between FPG and alpha and delta cell volumes were not significant (Fig. 4a, b). Conversely, delta cell volume was inversely correlated with $\log _{\mathrm{e}}$ NEFA, suggesting a potential toxic effect of increased levels of NEFA, which are observed in G3 and G4 animals in delta cells (Fig. 4c, $R^{2} 0.1926, p<0.05$ ). Delta cell volume positively correlated with beta cell volume (Fig. $4 \mathrm{~d}, R^{2}$ $0.2110, p<0.01)$.

\section{Correlation of plasma glucagon levels and beta, alpha and} delta cell volumes Plasma glucagon levels did not correlate significantly with either beta or alpha cell volume (ESM Fig. 1a, b), while glucagon levels showed a significant inverse correlation with delta cell volume (ESM Fig. 1c, $R^{2} 0.2696$, $p<0.01)$.
Pancreatic delta and beta cell apoptosis To explore the mechanisms involved in the reduction of both delta and beta cell volume we performed a TUNEL assay on pancreatic sections obtained from G1 and G4 baboons. In triple immunofluorescence experiments with antibodies against hormones, $\sim 5 \%$ of delta and $\sim 3.5 \%$ of beta cells were TUNEL positive (apoptotic) in G4 diabetic pancreases (Fig. 5e, f, h, i, k, 1), compared with control non-diabetic pancreases (G1 group) where no apoptotic delta cells $(p<0.05)$ and beta cells $(p<0.005)$ were observed (Fig. $5 \mathrm{~d}, \mathrm{~g}, \mathrm{j}, \mathrm{m})$.

To confirm the presence of apoptotic delta cells in diabetic pancreases, in both G1 and G4 pancreases we also performed double label immunohistochemical and triple immunofluorescence staining with antibodies directed against two additional apoptotic cell markers: M30 and CC-3 antibodies.

In G3 and G4 diabetic pancreases, the volume and the number of somatostatin-producing delta cells was greatly reduced compared with G1 control pancreases (Fig. 1k, l and ESM Fig. 2a, b). 
Fig. 4 Correlation between (a) alpha cell volume/islet volume and plasma glucose $\left(R^{2} 0.04, p=\right.$ $0.22,95 \% \mathrm{CI})$; (b) delta cell volume/islet volume and plasma glucose $\left(R^{2} 0.058, p=0.16,95 \%\right.$ CI); (c) $\log _{\mathrm{e}}$ NEFA and delta cell volume/islet volume $\left(R^{2} 0.1926\right.$, $p<0.05,95 \% \mathrm{CI}$ ); and (d) beta cell volume/islet volume and delta cell volume/islet volume $\left(R^{2}\right.$ $0.2110, p<0.01,95 \% \mathrm{CI}$ ) in baboons a
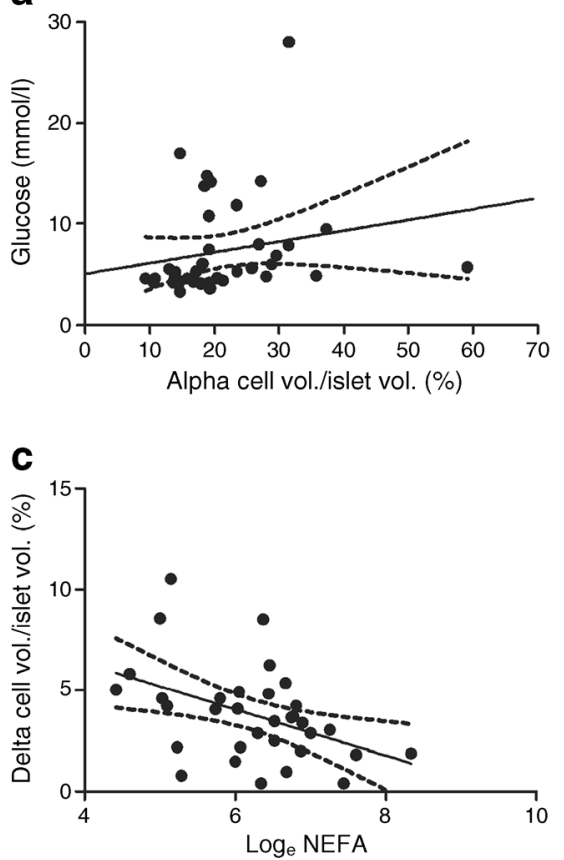

b
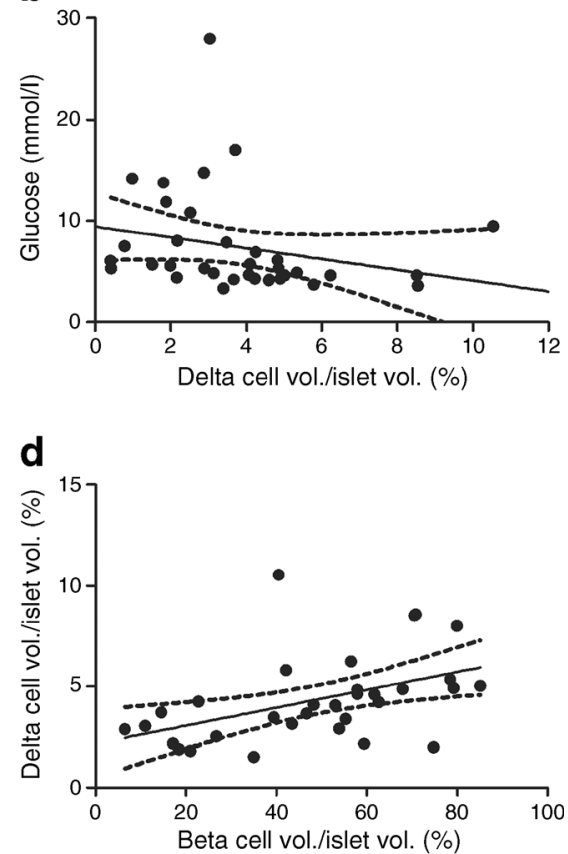

We observed M30-positive islet cells that were somatostatin negative, likely corresponding to insulin-positive beta cells as previously demonstrated [31] (ESM Fig. 2c, d, e). Using double label immunohistochemistry we were able to quantify that in diabetic pancreatic islets $\sim 3 \%$ of delta cells (Fig. $5 \mathrm{~m}$ and ESM Fig. 2f) and $2 \%$ of insulin-producing beta cells were positive for the M30 antibody (i.e. apoptotic cells). Conversely, in non-diabetic pancreases (G1 group) no apoptotic delta cells $(p<0.001)$ or beta cells $(p<0.001)$ were observed. These findings confirm and reinforce the data obtained by TUNEL (Fig. $5 \mathrm{~m}$ ). Finally, consistent with the data obtained by TUNEL confocal microscopy and M30 immunohistochemistry, we could also detect both insulin/CC-3-positive beta as well as somatostatin/CC-3-positive delta cells in G4 (type 2 diabetes) islets of Langerhans (ESM Fig. 3). The number of delta cells per islet area in a subset of baboon pancreases was decreased by $\sim 30 \%$ in baboon pancreases from G3-4 animals (ESM Fig. 4).

Immunoelectron microscopy While delta cells of G1 baboons were well preserved (Fig. 6a, b and ESM Fig. 5c), in G4 animals, delta cells showed the typical large and uniformly electron-dense secretory granules encircled by a tightly fitting membrane and were immunoreactive for somatostatin, but also presented signs of degeneration, such as pycnotic nuclei and cytoplasmic vacuoles, which are typical features of apoptotic cells (Fig. 6c, d and ESM Fig. 5d).

Electron microscopy At the ultrastructural level, the presence of increasing amyloid deposits was associated with signs of cellular injury, including intracellular vacuoles and pycnotic nuclei involving mainly beta cells, but also delta cells in G3 (impaired fasting glucose [IFG]) and G4 (type 2 diabetic) animals, while alpha cell morphology was unaffected by amyloidosis in G4 animals (Figs 7b, c, d and 8b, f). The degenerative/pro-apoptotic ultrastructural characteristics observed in beta and delta cells were also consistent with the decreases in beta and delta cell volume in diabetic animals.

\section{Discussion}

Several studies have shown that the pancreases of subjects with type 2 diabetes display a severe beta cell deficit due to increased beta cell apoptosis [16, 17, 37,38], and normal or increased alpha cell number [5, 13-15, 19]; interestingly, these alterations are also present in diabetic and insulin resistant/ obese baboons [31,33]. However, little is known regarding islet cell composition in prediabetic conditions such as IFG and impaired glucose tolerance [16]. We believe that another important unresolved question is related to the function and fate of the delta cells in type 2 diabetes. To learn more about these issues, we analysed the islet cell composition in the pancreases of baboons stratified into four quartiles of FPG levels spanning the NGT, IFG and type 2 diabetes ranges (G1-G4; Table 1).

We already reported that FPG levels in baboons are linearly correlated with islet amyloidosis [31]. In the present study, we confirm this finding by showing that as little as $0.83 \mathrm{mmol} / \mathrm{l}$ of FPG increase is associated with a significant increase in amyloid deposits that, remarkably, precede the changes in beta cell volumes (Fig. 1p). In fact, beta cell volumes were identical in 

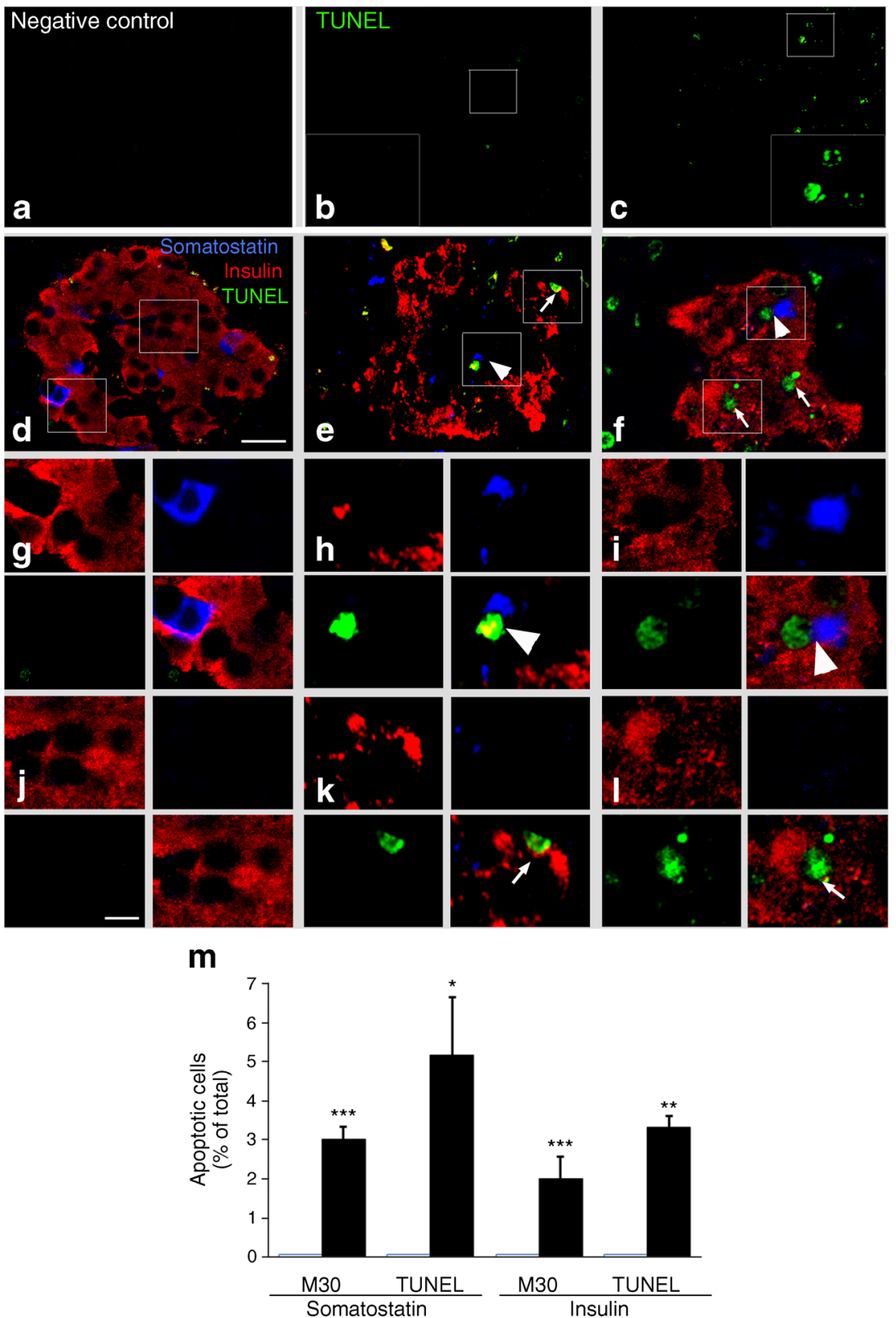

Fig. 5 Triple immunofluorescence staining showing apoptotic beta and delta cells in baboons with type 2 diabetes. To reveal the presence of apoptotic cells, a TUNEL assay was performed in pancreas sections from controls $(\mathbf{a}, \mathbf{b}, \mathbf{d}, \mathbf{g}, \mathbf{j})$ and two different $\mathrm{G} 4$ baboons with type 2 diabetes (c, e, f, h, i, k, l). (a) Negative control (secondary antibodies only); (b, c) TUNEL assay; (d-I) triple immunofluorescence staining with TUNEL (green), insulin (red) and somatostatin (blue). Representative TUNELpositive somatostatin-labelled cells are shown at high magnification $(\times 2.5)$ in $(\mathbf{g}-\mathbf{i})$. Representative TUNEL-positive insulin-labelled cells are shown at high magnification $(\times 2.5)$ in $(\mathbf{j}-\mathbf{l})$. TUNEL-positive nuclei were detected in a fraction of somatostatin-positive cells (blue,

arrowheads) and in insulin-positive cells (red, arrows), only in the pancreas of baboons with type 2 diabetes (a-f; scale bar, $20 \mu \mathrm{m}$ and $\mathbf{g}-\mathbf{-}$; scale bar, $10 \mu \mathrm{m})$. Quantification of apoptotic delta and beta cells detected using both TUNEL and M30 assay in normal and diabetic baboons is shown in (m). The number of M30-positive and TUNEL-positive delta or beta cells was counted in a total of 100 somatostatin- or insulin-immunoreactive cells in three different baboons for each group. Black bars, type 2 diabetic pancreas (G4); white bars, control pancreas (G1). Data are expressed as means \pm SD. ${ }^{*} p<0.05 ; * * p<0.01 ; * * *<0.001$ type 2 diabetes vs relative control

G1 and G2, decreased in G3 but without reaching statistical significance, and fell dramatically only in G4 (Fig. 1m). These data further strengthen the evidence that amyloid deposition is an early event in islet pathology in baboons and that amyloidosis is an important cause of beta cell death in humans, nonhuman primates and other species [16, 31, 38, 39].

Similarly to the beta cell, the alpha and delta cell volumes also did not change significantly between G1 and G2. Alpha cell volume increased sharply in G3 (Fig. 1n), while delta cell volume showed a remarkable decrease in this group (Fig. 1o). Thus, alterations in alpha and delta cell composition seemed to occur earlier than changes in beta cell volume. In G4, alpha 
Fig. 6 Immunogold electron microscopy showing a normal delta cell with the classical trumpet-like shape in a control G1 baboon; (a) scale bar 2,000 nm and (b) scale bar 1,000 $\mathrm{nm}$. The nucleus is well preserved and in the cytoplasm there are numerous secretory granules. At higher magnification (b), secretory granules are immunostained with an anti-somatostatin antibody and an anti-somatostatin gold-labelled antibody. In G4 baboons (c, scale bar 1,000 nm), the delta cell shows signs of degeneration including pycnotic nucleus and cytoplasmic vacuoles. At higher magnification (d, scale bar $500 \mathrm{~nm}$ ), secretory granules are immunostained with an antisomatostatin antibody and an anti-somatostatin gold-labelled antibody
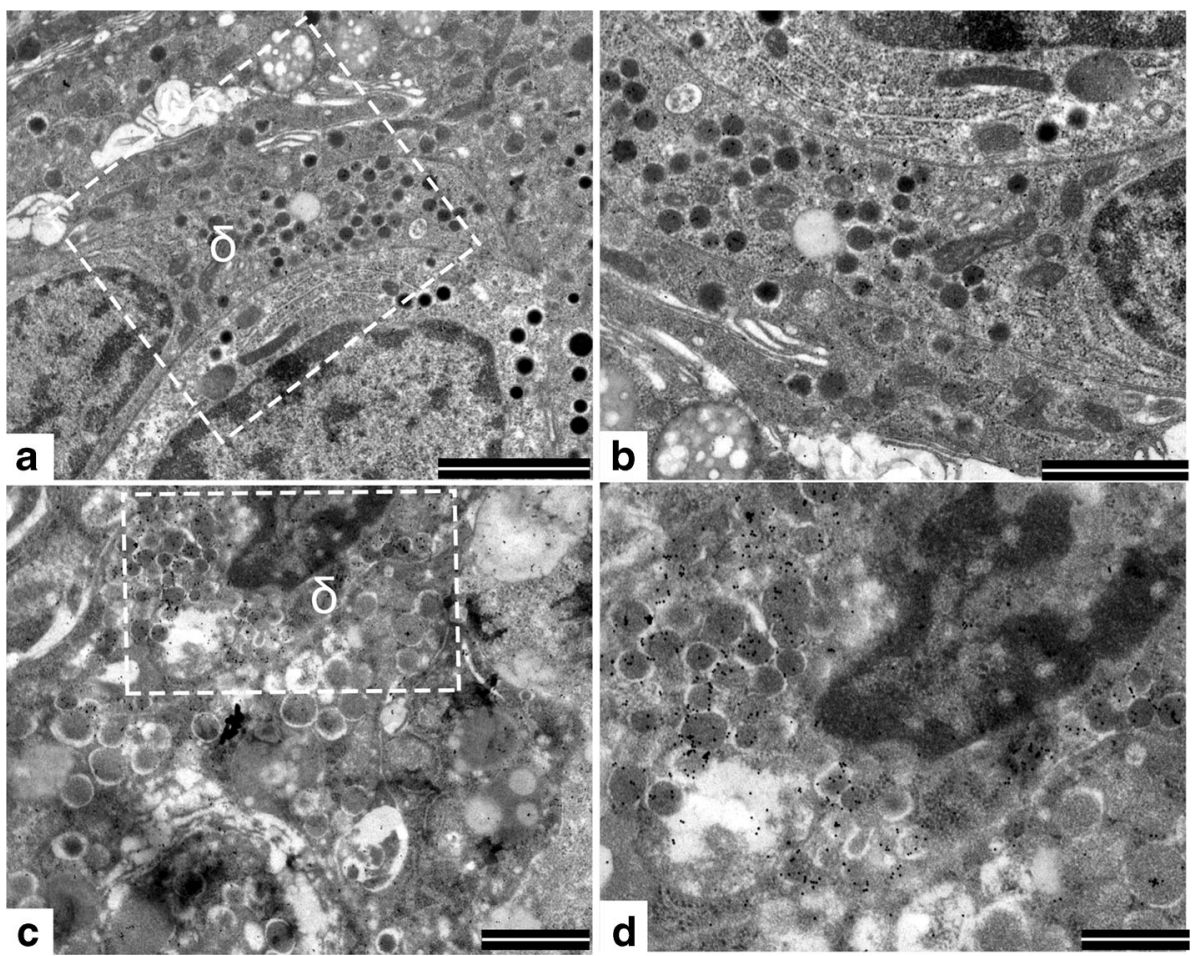

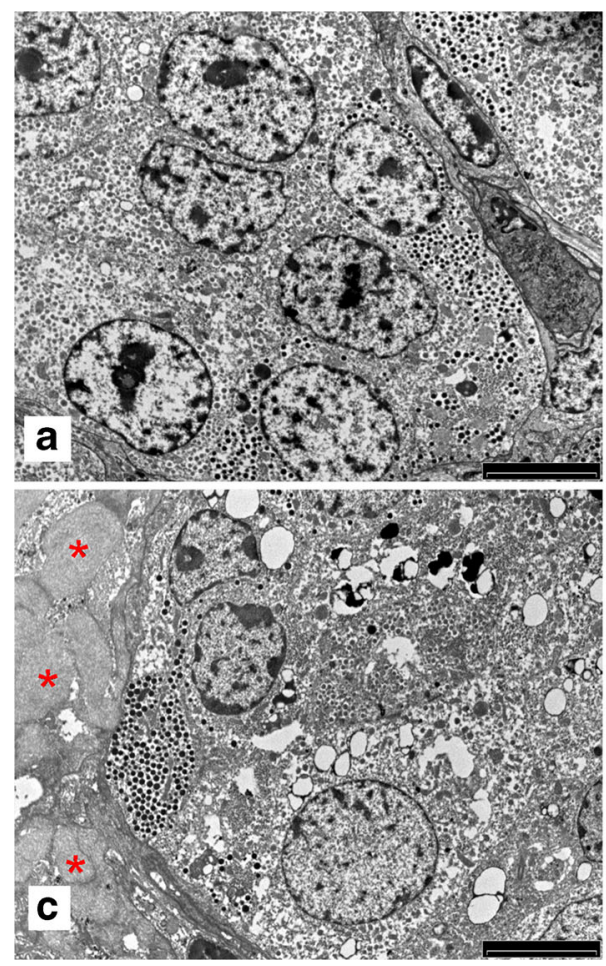

Fig. 7 Example of a normal islet in control pancreatic tissue (G1 animal); islet cells are all well granulated, do not show any sign of degeneration and amyloid fibrils are absent (a, scale bar $5 \mu \mathrm{m}$ ). Example of mild insular amyloidosis (G2 animal): some amyloid fibrils are accumulated in extracellular spaces (asterisks) and some cells show signs of degeneration (prepycnotic nuclei [arrow] and faint cytoplasmic vacuolisation) (b, scale bar $5 \mu \mathrm{m})$. Moderate amyloidosis (G3 animal): numerous amyloid fibrils are

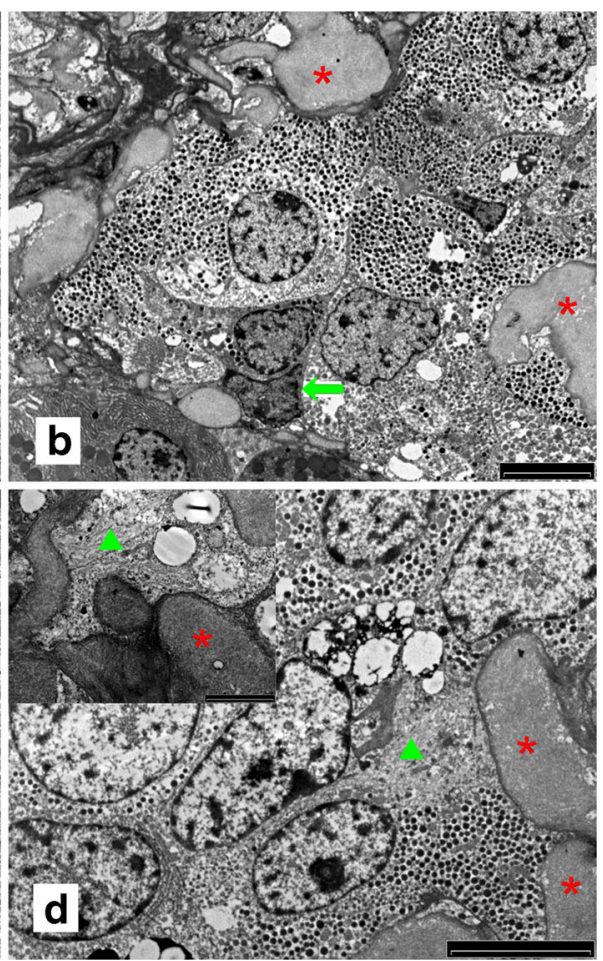

accumulated in extracellular spaces (asterisks) and cells show signs of degeneration, scarce secretory granules and numerous cytoplasmic vacuoles and lysosomes; (c, scale bar $5 \mu \mathrm{m})$. Severe amyloidosis (G4 animal): amyloid deposits are accumulated in both extracellular spaces (asterisks) and cell cytoplasm (triangle), as better shown in the inset. Some cells show significant degeneration, cytoplasmic condensation and vacuolation; d, scale bar $5 \mu \mathrm{m}$ ) 
Fig. 8 In a control baboon, beta (a, $\beta$, scale bar $2,000 \mathrm{~nm}$ ), alpha (c, $\alpha$, scale bar 2,000 nm), and delta (e, $\delta$, scale bar 2,000 nm) cells are well granulated and show normal nuclei. In a baboon with type 2 diabetes, beta (b, scale bar $5 \mu \mathrm{m}$ ) and delta (f, scale bar $1,000 \mathrm{~nm}$ ) cells show signs of degeneration including pycnotic nuclei and large cytoplasmic vacuoles, while alpha cells (d, scale bar $5 \mu \mathrm{m}$ ) show normal features. In the insets of figures (e) and (f), secretory granules are immunostained using antisomatostatin antibody and an anti-somatostatin gold-labelled antibody
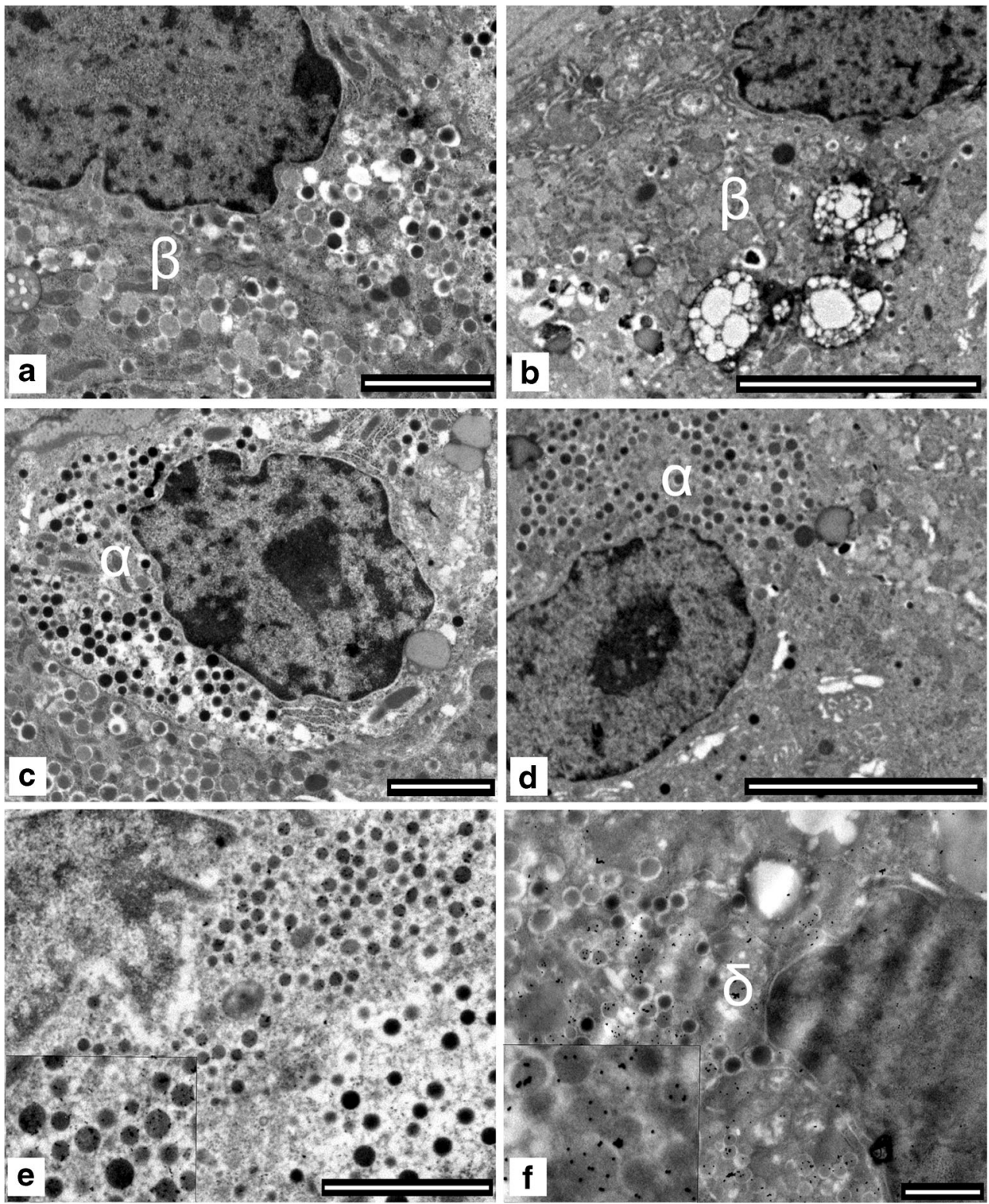

and delta cell volumes did not change further as compared with G3. This and previous studies indicate that in humans and baboons, alpha cells are resistant to various conditions of beta cell stress, and that delta cells are also involved in the islet remodelling that occurs in type 2 diabetes [20, 21, 40-44].

It has been suggested that metabolic stress and type 2 diabetes in mice can result in beta cell dedifferentiation into a progenitor-like stage followed by the conversion of a subpopulation of dedifferentiated beta cells into alpha cells [45]. Similar results have been shown in primary human beta cells that, when incubated in vitro under conditions of stress, loose insulin granules and transdifferentiate into alpha cells [46].

There is little information about delta cell fate in diabetes, but previous studies reported increased delta cell volumes in type 1 diabetes [47] as well as in type 2 diabetes [19] and in diabetes associated with cystic fibrosis [43]. Delta cell expansion has been interpreted as a compensatory adaptation to hyperglucagonaemia. These studies, however, have the limitation of being performed on a small number of subjects and in the presence of severe beta cell depletion, so that apparent delta cell hyperplasia might be relative to beta cell loss rather than absolute.

Furthermore, together with the evidence of reduced delta cell volumes, we here provide for the first time the direct evidence of ongoing delta cell death in type 2 diabetes. Confocal microscopy examination of control (G1) and G4 pancreatic tissues triple-stained for insulin, somatostatin and TUNEL showed that apoptotic delta cells were absent in pancreases from G1 baboons but present in those from G4 baboons (Fig. 5). Electron microscopy and immune-electron 
Fig. 9 Proposed dysfunctional islet remodelling in the natural history of type 2 diabetes. As glucose levels and amyloid deposits progressively increase, different anatomical and physiological changes occur in beta, alpha and delta cells leading to a dysfunctional islet remodelling and progression to type 2 diabetes. IAPP, islet amyloid polypeptide

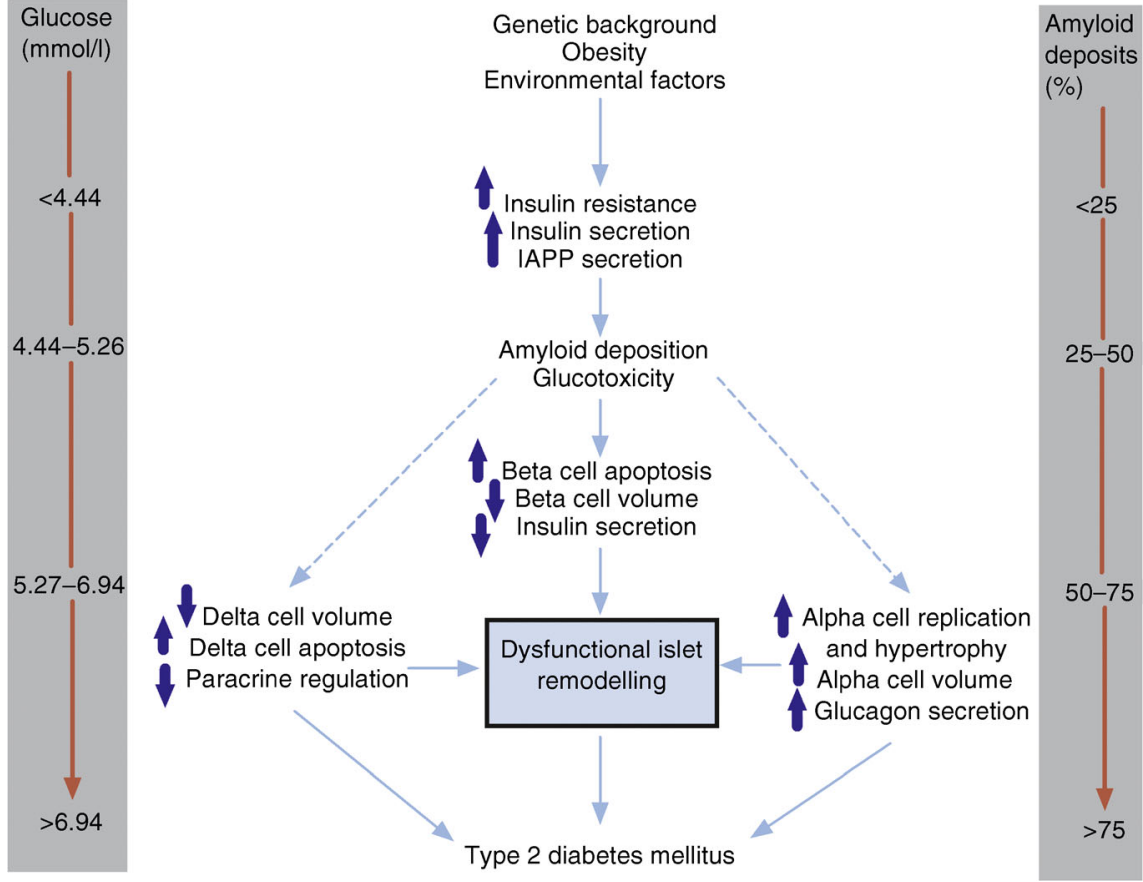

microscopy analysis of G4 baboon pancreases showed somatostatin-positive delta cells with ultrastructural degenerative features and fragmented pycnotic nuclei (Fig. 6 and ESM Fig. 5). Moreover, double immunohistochemical and triple immunofluorescence studies showed co-localisation of somatostatin and the apoptotic markers M30 and CC-3 in islet delta cells of diabetic baboons (ESM Figs 2, 3). The evidence that amyloid severity is inversely correlated to delta cell volumes (Fig. 2d) may suggest that delta cells, like beta cells, are also sensitive to amyloid toxicity. In contrast to beta cell volume (Fig. 3a), delta cell volume did not show a clear negative correlation with FPG (Fig. 4b). Nevertheless, similarly to beta cell volume, delta cell volume correlated inversely with NEFA levels (Figs 3b and 4c). Thus, delta cells appear resistant to glucose-toxicity but sensitive to lipotoxicity [48]. In spite of a slightly different sensitivity to hyperglycaemia, amyloid and NEFA, beta and delta cells share a common fate as their volumes are positively correlated with each other (Fig. 4d). Owing to the known negative paracrine effect of somatostatin on alpha cell secretion, loss of delta cells (in concert with the relative or absolute increase in alpha cell volume) can also play a role in insulin and glucagon secretory changes associated with type 2 diabetes. This possibility is supported by evidence that fasting glucagon concentrations are inversely correlated to delta cell volume (ESM Fig. 1c). Finally, a decrease in delta cell number (considering the negative paracrine effect of somatostatin on insulin secretion) could be viewed as a compensatory adaptation in a situation of beta cell deficiency.

We would like to propose that as glucose and amyloid increase within the islet, dysfunctional islet remodelling occurs that involves not only beta and alpha cells, but also delta cells (Fig. 9).
In conclusion, additional studies should be carried out to confirm the loss of delta cells in human type 2 diabetes and to explore the molecular mechanisms involved, and to investigate novel therapeutic options directed at preserving not only beta cells, but also delta cells.

Acknowledgements We thank M. Silva for pathology support and expert assistance in tissue processing (Texas Biomedical Research Institute, San Antonio, Texas, TX, USA). We also thank P. Zuo for performing insulin and glucagon RIA and NEFA determinations. Portions of this work were presented in abstract form at the 2014 Endocrine Society Meeting, Chicago, IL, USA. This work is dedicated to the memory of my beloved nephew Matteo Folli (17 April 1995-2 April 2015), who left us in the prime time of his life.

Funding This research was supported in part by NIH-NCRR grant P51 RR013986 to the Southwest National Primate Research Center and conducted in facilities constructed with support from Research Facilities Improvement Program Grant C06 RR014578 and C06 RR015456. FF was partially supported by NIH RO1 DK080148. FF is a visiting professor in the Department of Medicine and the Obesity and Comorbidities Research Center (OCRC), University of Campinas, Campinas, São Paulo State, Brazil, and is supported by FAPESP and CNPq, Brazil. He is on sabbatical leave from the University of Texas Health Science Center at San Antonio, TX, USA. LAV and MJAS are supported by OCRC and FAPESP, Brazil.

Duality of interest The authors declare that there is no duality of interest associated with this manuscript.

Contribution statement FF is responsible for the integrity of the study and conceived the study. RGM and FF performed experiments and generated, analysed and interpreted the data, wrote the manuscript and reviewed the final version of the manuscript. CP, GF, SL, CC, FS and SM performed experiments, analysed and interpreted the data, wrote the manuscript and contributed to the discussion and the final review of the 
manuscript. LMJC performed data quantification, analysed and interpreted the data and critically revised the manuscript for important intellectual content. LAV, MJAS and FB analysed and interpreted the data and critically revised the manuscript for important intellectual content. EJD and AD performed experiments, analysed and interpreted the data, wrote the manuscript, contributed to the discussion and reviewed the final version of the manuscript. All authors gave final approval of the version of the manuscript to be published.

\section{References}

1. Gannon M, Ray MK, van Zee K, Rausa F, Costa RH, Wright CV (2000) Persistent expression of HNF6 in islet endocrine cells causes disrupted islet architecture and loss of beta cell function. Development 127:2883-2895

2. Orci L, Unger RH (1975) Functional subdivision of islets of Langerhans and possible role of D cells. Lancet 2:1243-1244

3. Samols E, Stagner JI (1990) Islet somatostatin - microvascular, paracrine, and pulsatile regulation. Metabolism 39:55-60

4. Unger RH, Orci L (2010) Paracrinology of islets and the paracrinopathy of diabetes. Proc Natl Acad Sci U S A 107: 16009-16012

5. Gromada J, Franklin I, Wollheim CB (2007) Alpha-cells of the endocrine pancreas: 35 years of research but the enigma remains. Endocr Rev 28:84-116

6. Bonner-Weir S, Orci L (1982) New perspectives on the microvasculature of the islets of Langerhans in the rat. Diabetes 31:883-889

7. Unger RH, Orci L (1977) Possible roles of the pancreatic D-cell in the normal and diabetic states. Diabetes 26:241-244

8. Bonner-Weir S, O'Brien TD (2008) Islets in type 2 diabetes: in honor of Dr. Robert C. Turner. Diabetes 57:2899-2904

9. Bosco D, Armanet M, Morel P et al (2010) Unique arrangement of alpha- and beta-cells in human islets of Langerhans. Diabetes 59: 1202-1210

10. Cabrera O, Berman DM, Kenyon NS, Ricordi C, Berggren PO, Caicedo A (2006) The unique cytoarchitecture of human pancreatic islets has implications for islet cell function. Proc Natl Acad Sci U S A 103:2334-2339

11. Quinn AR, Blanco CL, Perego C et al (2012) The ontogeny of the endocrine pancreas in the fetal/newborn baboon. J Endocrinol 214: 289-299

12. Orci L (1982) Macro- and micro-domains in the endocrine pancreas. Diabetes 31:538-565

13. Clark A, Wells CA, Buley ID et al (1988) Islet amyloid, increased A-cells, reduced $B$ cells and exocrine fibrosis: quantitative changes in the pancreas in type 2 diabetes. Diabetes Res 9:151-159

14. Yoon KH, Ko SH, Cho JH et al (2003) Selective beta-cell loss and alpha-cell expansion in patients with type 2 diabetes mellitus in Korea. J Clin Endocrinol Metab 88:2300-2308

15. Sakuraba H, Mizukami H, Yagihashi N, Wada R, Hanyu C, Yagihashi S (2002) Reduced beta-cell mass and expression of oxidative stress-related DNA damage in the islet of Japanese type II diabetic patients. Diabetologia 45:85-96

16. Butler AE, Janson J, Bonner-Weir S, Ritzel R, Rizza RA, Butler PC (2003) Beta-cell deficit and increased beta-cell apoptosis in humans with type 2 diabetes. Diabetes 52:102-110

17. Folli F, Okada T, Perego C et al (2011) Altered insulin receptor signalling and beta-cell cycle dynamics in type 2 diabetes mellitus. PLoS One 6, e28050

18. Dunning BE, Gerich JE (2007) The role of alpha-cell dysregulation in fasting and postprandial hyperglycemia in type 2 diabetes and therapeutic implications. Endocr Rev 28:253-283
19. Iki K, Pour PM (2007) Distribution of pancreatic endocrine cells including IAPP-expressing cells in non-diabetic and type 2 diabetic cases. J Histochem Cytochem 55:111-118

20. Unger RH, Dobbs RE, Orci L (1978) Insulin, glucagon, and somatostatin secretion in the regulation of metabolism. Annu Rev Physiol 40:307-343

21. Ludvigsen E, Olsson R, Stridsberg M, Janson ET, Sandler S (2004) Expression and distribution of somatostatin receptor subtypes in the pancreatic islets of mice and rats. J Histochem Cytochem 52: 391-400

22. Hauge-Evans AC, King AJ, Carmignac D et al (2009) Somatostatin secreted by islet delta-cells fulfills multiple roles as a paracrine regulator of islet function. Diabetes 58:403-411

23. Patel YC, Pierzchala I, Amherdt M, Orci L (1985) Effects of cysteamine and antibody to somatostatin on islet cell function in vitro. Evidence that intracellular somatostatin deficiency augments insulin and glucagon secretion. J Clin Invest 75:1249-1255

24. D'Alessio DA, Fujimoto WY, Ensinck JW (1989) Effects of glucagonlike peptide I-(7-36) on release of insulin, glucagon, and somatostatin by rat pancreatic islet cell monolayer cultures. Diabetes 38:1534-1538

25. Guenifi A, Ahren B, Abdel-Halim SM (2001) Differential effects of glucagon-like peptide-1 (7-36)amide versus cholecystokinin on arginine-induced islet hormone release in vivo and in vitro. Pancreas 22:58-64

26. Heller RS, Aponte GW (1995) Intra-islet regulation of hormone secretion by glucagon-like peptide-1-(7-36) amide. Am J Physiol 269:G852-G860

27. Silvestre RA, Rodriguez-Gallardo J, Egido EM, Marco J (2003) Interrelationship among insulin, glucagon and somatostatin secretory responses to exendin-4 in the perfused rat pancreas. Eur J Pharmacol 469:195-200

28. Vieira E, Salehi A, Gylfe E (2007) Glucose inhibits glucagon secretion by a direct effect on mouse pancreatic alpha cells. Diabetologia 50:370-379

29. Chavez AO, Gastaldelli A, Guardado-Mendoza R et al (2009) Predictive models of insulin resistance derived from simple morphometric and biochemical indices related to obesity and the metabolic syndrome in baboons. Cardiovasc Diabetol 8:22

30. Chavez AO, Lopez-Alvarenga JC, Tejero ME et al (2008) Physiological and molecular determinants of insulin action in the baboon. Diabetes 57:899-908

31. Guardado-Mendoza R, Davalli AM, Chavez AO et al (2009) Pancreatic islet amyloidosis, beta-cell apoptosis, and alpha-cell proliferation are determinants of islet remodeling in type-2 diabetic baboons. Proc Natl Acad Sci U S A 106:13992-13997

32. Kamath S, Chavez AO, Gastaldelli A et al (2011) Coordinated defects in hepatic long chain fatty acid metabolism and triglyceride accumulation contribute to insulin resistance in non-human primates. PLoS One 6, e27617

33. Guardado-Mendoza R, Jimenez-Ceja L, Majluf-Cruz A et al (2013) Impact of obesity severity and duration on pancreatic beta- and alpha-cell dynamics in normoglycemic non-human primates. Int J Obes (Lond) 37:1071-1078

34. Freere RH, Weibel ER (1967) Stereologic techniques in microscopy. J R Microsc Soc 87:25-34

35. Mandarim-de-Lacerda CA (2003) Stereological tools in biomedical research. An Acad Bras Cienc 75:469-486

36. Matthews DR, Hosker JP, Rudenski AS, Naylor BA, Treacher DF, Turner RC (1985) Homeostasis model assessment: insulin resistance and beta-cell function from fasting plasma glucose and insulin concentrations in man. Diabetologia 28:412-419

37. Lupi R, del Prato S (2008) Beta-cell apoptosis in type 2 diabetes: quantitative and functional consequences. Diabetes Metab 34(Suppl 2):S56-S64 
38. Jurgens CA, Toukatly MN, Fligner CL et al (2011) Beta-cell loss and beta-cell apoptosis in human type 2 diabetes are related to islet amyloid deposition. Am J Pathol 178:2632-2640

39. Westermark GT, Westermark P (2013) Islet amyloid polypeptide and diabetes. Curr Protein Pept Sci 14:330-337

40. Di Cairano ES, Davalli AM, Perego L et al (2011) The glial glutamate transporter 1 (GLT1) is expressed by pancreatic beta-cells and prevents glutamate-induced beta-cell death. J Biol Chem 286: 14007-14018

41. Federici M, Hribal M, Perego L et al (2001) High glucose causes apoptosis in cultured human pancreatic islets of Langerhans: a potential role for regulation of specific Bcl family genes toward an apoptotic cell death program. Diabetes 50:1290-1301

42. Fontes G, Zarrouki B, Hagman DK et al (2010) Glucolipotoxicity age-dependently impairs beta cell function in rats despite a marked increase in beta cell mass. Diabetologia 53:2369-2379

43. Soejima K, Landing BH (1986) Pancreatic islets in older patients with cystic fibrosis with and without diabetes mellitus: morphometric and immunocytologic studies. Pediatr Pathol 6:25-46
44. Menge BA, Gruber L, Jorgensen SM et al (2011) Loss of inverse relationship between pulsatile insulin and glucagon secretion in patients with type 2 diabetes. Diabetes 60:2160-2168

45. Talchai C, Xuan S, Lin HV, Sussel L, Accili D (2012) Pancreatic beta cell dedifferentiation as a mechanism of diabetic beta cell failure. Cell 150:1223-1234

46. Spijker HS, Ravelli RB, Mommaas-Kienhuis AM et al (2013) Conversion of mature human beta-cells into glucagon-producing alpha-cells. Diabetes 62:2471-2480

47. Orci L, Baetens D, Rufener C et al (1976) Hypertrophy and hyperplasia of somatostatin-containing D-cells in diabetes. Proc Natl Acad Sci U S A 73:1338-1342

48. Collins SC, Salehi A, Eliasson L, Olofsson CS, Rorsman P (2008) Long-term exposure of mouse pancreatic islets to oleate or palmitate results in reduced glucose-induced somatostatin and oversecretion of glucagon. Diabetologia 51:1689-1693 